\title{
Boys, learning to become bad: An uncomfortable truth, and an equally difficult solution?
}

\section{Rod Wills}

University of Auckland

While New Zealand has seen significant change in many areas of state provided social services, government funded education has been relatively 'buffered' from direct political intervention, until the return of the present government in the general election of 2011.

The discussion that follows makes the proposal for political intervention in the highly gendered area of early childhood education (ECE); indeed such an intervention may bring about a much-needed change in the life path of many young at risk boys.

\section{The problem}

Since their election in 2011 a concerted effort has been made by the National coalition government of New Zealand to address what is often referred to as the 'tail' in student achievement. Data reported by the Ministry of Education (2011) of the lower quartile of achievement in the literacy, numeracy and writing levels of students, shows a correlation when compared with data reported by the Child Poverty Action Group (2008). This document investigated the impact of living in conditions of relative poverty, attending schools that were described as 'hard to staff' and being labeled as being 'hard to teach'. The majority of those students were of Mäori or Pasifika cultural heritage.

\section{School management, choice and quality}

Since 1990 a de-centralised managerial model had been in place throughout the compulsory sector of education in New Zealand. Community elected boards of trustees, together with the principal, hold the responsibility for running government funded 
schools. A feature of the educational reforms had been the marketization of education; where parent choice and competition for school enrolments was expected to lift the 'quality' of publicly funded education. The Educational Review Office (ERO) is an independent central agency that evaluates the performance of all schools and educational organisations. The ERO reports publically on matters of education quality and school performance; making recommendations on issues and concerns to the Minister and Ministry of Education.

The present National led coalition government is in its second term of control and holds a majority of two seats in parliament. The coalition can be characterized as looking toward business and commerce for direction and detail in policy.

\section{Policy, politics and political arrangements}

Three recent policy interventions demonstrate the use of neo-liberal ideology by the current government to change the state education system;

- Since 2010, amendment to the Education Act has required school boards to measure student achievement against National Education Standards. The policy was justified politically, 'what the electorate voted for!' In 2012, the Ministry of Education released this data for the first time. With this mechanism implemented policy is to be developed to allow the development of performance-based pay for teachers.

- In 2012, responding to Treasury driven calls for savings, the Minister of Education announced that class sizes would be increased. Citing a synthesis of meta-analyses of studies detailing student achievement (Hattie, 2009) the argument was promoted that the teacher to pupil ratio in classes did not impact upon 'quality teaching'.

- An agreement made 'over a cup of tea' enabled the right wing party ACT (the Association of Consumers and Taxpayers) to maintain a seat in parliament and provide support to the coalition government. The 'trade off' for the support from the ACT party was to put a working group in place to establish 'charter schools' by 2013. 
The public and education sectors response to these interventions was both negative and condemnatory. The acceptability of the proposed policy change is monitored through electoral polling. Ongoing lowered levels of public acceptance and response to the implementation of the National Education Standards led to the sacking of the Minister a year after the policy was released. The proposed increase of teacher ratios to cut costs generated such a backlash that a policy 'u turn' was performed by the Minister. Within four weeks the policy had been withdrawn. The project to establish 'charter schools' carried a risk of legitimacy. As the ACT party promoted the policy, the Minister of Education distanced herself from the public and education sector reactions.

Against this backdrop of 'ideologically based' projects other areas in the education system had been overlooked. Those in the 'too hard' basket often gaining a reaction but failing to attract sufficient policy work to develop and implement a response leading to desired change.

Significant amongst these had been the problem of young boys who failed to develop the 'pro-social' behavioural skills to remain sufficiently engaged in school to be adequately prepared for employment, further training or tertiary education. Upon leaving school they were at high risk of being on the 'conveyor belt' to the prison system. The issues for this group have not been ignored, over the past decade reviews, reports and commentary had been made, however the connection to early childhood education and the absence of male educators, and the role models they might present, was left in silence.

\section{Concerns about boys' behaviour}

In 2001, the Corrections Department report, About Time, detailed alternative strategies to reduce the high rate of incarceration in New Zealand, second in the world behind the USA. The costs this brought to the economy were identified: "An adult male lifetime offender generates $\$ 3 \mathrm{~m}$ in costs to victims and taxpayers" (Department of Corrections 2001, p. 29). The report presented a range of options focused toward youth and early intervention with young children. "Prevention starts with our children, we must stop children from socially and economically disadvantaged families growing up into a life of crime" (Department of Corrections, 2001, p. v). 
The complexity of the issues identified by the report contributed to the lack of progress toward resolution. The problems remained and were to be targeted as 'student behaviour'. This became the focus of a government led 'summit' in 2007. Six years after the About Time report the two-day event for leaders in education, health and welfare commenced a new cycle of policy work aiming to address behavioural issues in schools. An inter-agency working group was established; its sponsors were the ministries of education, health and social development who provided the brief, to address conduct disorder and severe antisocial behaviour in children.

The focus was placed upon young children who failed to develop pro-social skills.

Conduct problems are the single most important predictor of later chronic antisocial behaviour . . . the pathway for many affected young people typically leads on to youth offending, family violence and, ultimately, through to serious adult crime (Inter-agency Working Group, 2007, p. 1).

A further study showed that the approaches available for the identification and referral for very young children were "particularly inadequate" (Inter-agency Working Group, 2007, p. 22), however the view was offered that young children in early childhood education could be supported as well as "teachers are often able to manage problem behaviours without recourse to outside support" (Inter-agency Working Group, 2007, p. 22).

\section{The youth court view}

Addressing the 2012 conference of the School Trustees Association the Principal Youth Court Judge Andrew Becroft implored schools to work to retain the 'hard to teach' students, the boys over fourteen so often suspended from school, and detailed how patterns of anti-social behaviour formed the pathway to becoming career criminals. In his address he elaborated that: "very few serious youth offenders are from stable two parent homes" while he was at pains not to say that solo parents breed criminals and not making judgments about separation, he was clear that, "most serious young offenders lack a positive, male, role model" (Address to NZ School Trustees Association conference 14 July, 2012). 


\section{Early childhood education - the beginning of structured learning}

In New Zealand early childhood education is not compulsory. Nevertheless the current Statement of Intent 2012 -2017 signals the importance of early childhood education. By 2014 the goal is that ninety-six percent of children will have attended early childhood education prior to starting school. Amongst these will be 3,215 children from targeted participation projects, focusing on low-income communities. (Ministry of Education, 2012, p. 24).

Setting the desired level of participation, and targeting children from the groups that predominate the data of underachievement at school raises questions about the teaching that is most beneficial. The politicians who boldly intervened in other areas of education should raise the issue of the lack of male teachers in early childhood education. The absence of men denies young boys the opportunity to engage with a positive male role and the opportunity to learn from those experiences. The detail of male participation in this workforce paints a depressing picture.

\section{Men in early childhood education}

Data released by the Ministry of Education (2012) that summarises the numbers of teachers in ECE by service type, gender and qualification shows the gradual increase in the numbers of qualified male teachers working in kindergartens and private centres; the later being categorized as providing education and care. While there has been an increase in these areas of the sector, further scrutiny reveals a dismal portrayal of a workforce with astonishingly low numbers of men. Since 2005, the percentage has increased from $0.95 \%$ to $1.83 \%$ of men as a total of the workforce. Kindergartens in 2011 employed 51 men, up from 26. The private provider sector (Education \& Care) employed 322 qualified male staff, up from 104 in 2005. In 2011 the sector workforce totaled 20,664 qualified staff.

\section{Political intervention for change}

Concern should be expressed over the inability of the early childhood sector to provide boys with quality education. The lack of male role models arising from the traditional staffing patterns needs to be the subject of intervention. This intervention should be 
politically driven, as it is unlikely to be signaled as a policy problem by the present highly gendered ECE sector. And why should this position seem extreme? We are about to commence the drug and alcohol testing of the recipients of the Youth Guarantee Scheme and counsel the teenage daughters of sole mothers receiving the Domestic Purpose Benefit to be implanted with long-term contraceptives. Really - yes! Quotas for men in ECE - why not!!!

\section{References}

Department of Corrections (2001). About time: Turning people away from a life of crime and reducing re-offending. Wellington: Author.

Hattie, J. A. C. (2009). Visible learning: A synthesis of over 800 meta-analyses relating to achievement. London: Routledge.

Inter-Agency Working Group (2007). Inter-agency plan for Conduct disorder/severe antisocial behaviour. Wellington: Ministry of Social Development.

Ministry of Education (2011). Annual report 2011. Wellington: Author.

Ministry of Education (2012). Statement of intent 2012 - 2017. Wellington: Author.

St. John, S., \& Wynd, D. (Eds.), (2008). Left behind: How social and income inequalities damage New Zealand children. Auckland: Child Poverty Action Group.

\section{Biographical Notes}

Rod Wills is a Senior Lecturer in Education Studies (Disability) at the School of Critical Studies in Education, Faculty of Education, University of Auckland. He contributes to a range of undergraduate and post-graduate courses, with emphasis on diversity and disability studies. His research interests are in areas of; education policy and disability, parents' advocacy and special education, the use of disability arts as a vehicle for adult education. His doctoral study with Griffith University examines areas of cognitive dependency, parental caregiving and medical education.

Rod has held leadership roles in the disability sector for over 25 years. He led a multidisciplinary clinical team for the Auckland Area Health Board during the deinstitutionalisation of adults with an intellectual disability. For the last three years he has been the Chairman of the Interacting Disability Theatre Trust and takes an active role in the delivery of disability theatre, and disability arts in the Auckland region. Rod is the parent of a woman with Down syndrome. 